of Rochester. At the close of this service an address on Trevithick will be given by Mr. L. St. L. Pendred, and a wreath will be placed on the memorial which recalls Trevithick's death at the Bull Inn, Dartford, on April 22, 1833. At evensong at 3 p.m. in Westminster Abbey on Sunday, special reference will be made to the centenary by the preacher, the Ven. Archdeacon V. F. Storr, and at the end of the service a chaplet will be placed beneath the Trevithick window in the north aisle of the Abbey. Finally, on Monday, April 24, at 6 p.m., a memorial lecture will be delivered by Prof. C. E. Inglis, at the Institution of Civil Engineers, Great George Street, S.W.1, by kind invitation of the Council. The chair will be taken by Sir Murdoch Macdonald.

\section{Unemployment and the Schools}

AT the National Union of Teachers' annual conference on April 15 the new president, Mr. H. N. Penlington, of Hemsworth, Yorkshire, opened his address with the declaration that unemployment is the outstanding problem of our age; and this leitmotif dominated the rest of his discourse under the headings of school objectives, school buildings and school staffs. With the ever-increasing displacement of human labour by machinery, leisure seems destined to bulk more and more largely in human life, and it follows that preparation for life must increasingly include equipment for commendable uses of leisure. Unemployment in the building trade could be substantially relieved by carrying into effect school building programmes in respect of more than fourteen hundred schools which are admittedly insanitary or in other ways totally unfit for their purpose. Not less urgent is the need of relief of overcrowding of classes, in nearly eight thousand of which the enrolment exceeds fifty pupils. Meanwhile, the number of unemployed teachers grows and is expected to reach between two and three thousand by September next. If the school-leaving age should remain unchanged, the number of 'school-leavers' this year will be about half a million-an exceptionally large number-and a large proportion of these must go to swell the numbers of the unemployed. The time is opportune, Mr. Penlington suggested, for raising the school-leaving age, and he emphasised the dangers of an unenlightened and reactionary policy spreading discontent, already rife, on account of the 'cuts' in the Burnham scales.

\section{Herrings and the Origin of Petroleum}

Ir would seem at first a far cry from a modern herring catch to petroleum genesis, but a recent discovery off the coast of Alaska proves this to be by no means the case. Some twenty or thirty years ago a boat loaded with herrings was wrecked off Admiralty Island, Alaska, and recently samples of the sea deposits, near to where the wreck occurred, were dredged up and sent to the United States Geological Survey in order that an analysis could be made of an unusual waxy substance which they contained. The investigation was in charge of Dr. R. C. Wells of the Survey, who proved that the wax was a complex compound formed of decomposition products of the fat in the fish, combined with calcium and magnesium salts of the sea-water. It was further found that high-temperature distillation of this wax gave rise to an oil having affinities with petroleum. In all theories of organic origin of petroleum the most difficult part to understand is precisely how the original substance underwent conversion into the hydrocarbon oil which we recognise in crude petroleum and, while we may visualise the environment under which these changes took place, the actual chemical mechanism in. volved is far more difficult to conceive.

As a report issued by Science Service (Feb. 14) states in connexion with this matter, the fact that the fatty acids formed by decomposition of the fish united into a complex waxy salt with minerals in the sea-water suggests that something of the same sort may have happened in the ancient seas in which petroliferous deposits have been laid down. The only criticism we have to make in this instance is that practically all scientific evidence available tends to show that the time factor is of fundamental importance in the production of petroleum, quite apart from the environment in which it may have been conceived. In this particular illustration, it would seem that comparatively little fundamental change could have taken place in the organic substance deposited by this wreck, and we question whether the results of distilling this wax-like material are really indicative of more than would be expected from interaction between animal substance and sea salts, interactions which must, in point of fact, be constantly in process in every sea and in all kinds of environments.

\section{Mechanical Transport in India}

During the last forty years, railways have been a great boon to India, but now their practical monopoly is being seriously challenged by vehicles propelled along roads by internal combustion engines. The paper read to the Indian Section of the Royal Society of Arts on March 10 by Col. F. P. Barnes on the development of mechanical transport is therefore a timely one. $\mathrm{He}$ computes that the number of motor vehicles in India is about 160,000 and is rapidly increasing. But this only gives 1 vehicle for every 2,000 inhabitants. This compares with 1 in 5 in the United States and 1 in 32 in Great Britain. There is thus plenty of room for development. Amongst the advantages of motor transport are that it employs a large number of people, it adds to the amenities of life and has a civilising effect. It now gives employ. ment to about 200,000 people in India. Instead of using the tonga and bullock wagon, the business man uses a car and can cover a much larger area in a much shorter time. He can also send his family to the hills in comfort. The eivilising effect is shown in Waziristan, where a great circular road has been constructed running through a country of tribesmen who, a few years ago, were formidable enemies of the British. The road was largely constructed by men who had fought against the British and some of them 
are now employed as policemen to patrol it. Many passengers now leave their rifles at home, showing that law and order is being established. Col. Barnes pointed out the great advantages that would accrue to the railways if the motor industry were developed so as to feed and not to compete with them. Mechanical transport in India has received little encouragement from the Government. It has been mainly regarded as a source of extra revenue and heavily taxed. Despite this, it has flourished and is now one of the principal industries in the country. There can be little doubt that if it is encouraged, there will be a great future in India for mechanical transport.

\section{Meteor Crater, Arizona}

THE Meccano Magazine for March contains an illustrated article on this unique formation. The photographs give a vivid idea of the force of the impact, which shattered the rocks, and forced up great blocks of limestone. Mr. D. M. Barringer has for many years been making efforts to discover the meteor itself. Two vertical shafts were sunk near the centre of the crater, but there was no success, and the work was impeded by the influx of water, which turned the powdered rock-flour into a quicksand. Eventually experiments on the impact of projectiles led to the conclusion that oblique impacts give a nearly circular.depression: $\mathrm{Mr}$. Barringer had at first assumed that the meteor would lie under the centre of the pit, but further examination of the shattered rocks suggested that it had come from the north and was likely to lie under the southern edge of the pit. A shaft is now being sunk in undisturbed soil a quarter of a mile to the south of the pit; this will be continued to a depth of some $1,400 \mathrm{ft}$., and then a horizontal shaft will be run to the north, in the hope of encountering the meteor, which may be either a single great metal mass (in which case it is estimated to weigh some ten million tons) or a compact swarm of smaller masses. There is still some trouble from water, but it is hoped to overcome this by surrounding the shaft with reinforced concrete. Mr. Barringer has now been carrying on his arduous exploration for many years, and certainly deserves success. The article makes some estimates as to the date of the impact; it cannot be less than seven centuries ago, from the evidence of old trees growing on the rim; and it is thought to be less than five thousand years ago, from the fact that little erosion of the scattered blocks has taken place. Also the native Indians have a vague tradition of a fiery descent from heaven. Probably it may be dated between one and two thousand years ago.

\section{Mind as a Living Process}

THE second of the L. T. Hobhouse Memorial Trust lectures was given by Dr. Charles S. Myers on May 19, 1932 , and has been published under the title of "The Absurdity of any Mind-Body Relation" (Oxford University Press. 2s. net). Dr. Myers maintains the view that any relation between mind and body is absurd because mental activity and living bodily activity are identical. The mechanical principles of the natural sciences are only an abstraction from the quasi-dual set of principles-direction and mechanism -that govern the entire un verse. Each is an ab. straction from the whole activity. Mind and life are identical properties of living matter, which differs from lifeless matter in its inherent, purposive, selfdirective, and finally purposeful struggle for existence. From this point of view then, the hypotheses of psycho-physical parallelism, of interactionism, and of either form of monism are untenable. Dr. Myers quotes with approval from Hobhouse to the effect that life arose not from dead elements, but from pre-material elements which also gave rise to inanimate matter, so that all life contains a germ of mind. Mind is thus to be regarded as the expression of the directive activity of living matter. This directive activity is to be regarded as the highest unitary activity of the nervous system : the lower directive activities may not always be in harmony with the highest and hence the mental conflicts, conscious and unconscious. Dr. Myers discusses the relation of the cognitive, affective and conative aspects of experience and the part played by instinct and intelligence. The point of view is most lucidly expressed and raises interesting questions for philosophy, psychology, biology and physical science. It is worthy of note that ancient and medieval thought realised the problem also, and that only from the context in many writings can one know whether the word 'anima' is to be translated life or mind.

\section{Origin of the Irish Flora and Fauna}

In his presidential address delivered last November to the Royal Irish Academy, Dr. R. Lloyd Praeger returned to a subject which has occupied his attention for forty years-the problem of the Irish flora and fauna (Proc. Roy. Irish Acad., 41, 125). The problem has been much discussed, but always with an obscurity of background due to absence of fossil evidence which might give the clue to the routes and periods of past immigrations. In such circumstances conclusions assume a personal interpretation and Dr. Praeger's view is that much of the present flora and fauna reached Ireland over land-surfaces, either during inter-glacial (Aurignacian) times, or in the same way after the ice had finally passed away, or probably during both periods. Certain plants and animals found with these immigrants, including the American and probably the Lusitanian element, are older than these, and survived the main glaciation. These oldest elements migrated northward in pre-glacial times along the western European coast line, or eastward from America when the intervening barriers of sea were at least much less formidable than they are at present.

\section{Migration of Red Grouse}

THE University of Aberdeen inquiry into the move. ments of the red grouse would welcome the co. operation of owners or tenants of grouse-moors willing to ring young or adult birds during the present season. Rings, with instructions for their use, may be obtained from Prof. James Ritchie, Marischal College, Aberdeen. 